\title{
Content validation of a clinical assessment instrument for stair ascent and descent in individuals with hemiparesis
}

\author{
Mavie A. Natalio ${ }^{1}$, Christina D. C. M. Faria ${ }^{2}$, Luci F. Teixeira-Salmela ${ }^{2}$, \\ Stella M. Michaelsen ${ }^{1}$
}

\begin{abstract}
Background: Among the current instruments used to assess stair ambulation, none were observed that specifically evaluated the quality of movement or biomechanical strategies adopted by stroke patients. Objective: To evaluate the content validity of a clinical instrument designed to identify the qualitative and kinematic characteristics and strategies adopted by stroke patients during stair ascent and descent. Method: The first developed version, which comprised 80 items, had its content evaluated by an expert panel, which was composed of 9 well-known national and international professionals who are involved in stroke rehabilitation. The content validity index (CVI) and modified Kappa coefficients were employed for the statistical analyses. The items that demonstrated a CVI $\geq 0.80$ and Kappa $\geq 0.75$ were considered valid. Results: The content validation was performed in three stages. The final version of the instrument consisted of 38 items, which were divided into descriptive (8 items), a General Characteristics Domain (16 items) and adopted strategies (14 items) during stair ascent and descent. The total scores ranged from zero to 70 and zero to 74 for ascent and descent, respectively. Lower scores corresponded with better performance. Conclusion: Despite the satisfactory results obtained during the process of content validation, other psychometric properties of the instrument are necessary and must be evaluated.
\end{abstract}

Keywords: physical therapy; stroke; evaluation; biomechanics.

\section{HOW TO CITE THIS ARTICLE}

Natalio MA, Faria CDCM, Teixeira-Salmela LF, Michaelsen SM. Content validation of a clinical assessment instrument for stair ascent and descent in individuals with hemiparesis. Braz J Phys Ther. 2014 July-Aug; 18(4):353-363. http://dx.doi.org/10.1590/ bjpt-rbf.2014.0052

\section{Introduction}

The ability to ascend and descend stairs is considered a key indicator of functional independence $e^{1-7}$. Individuals with hemiparesis due to stroke report difficulty in performing this activity, even one year after the episode ${ }^{8-11}$. Although the kinematic gait characteristics of patients with hemiparesis have often been described in the literature ${ }^{12-15}$, a complete and comprehensive assessment instrument for stair ascent/descent has not been developed.

An assessment of ascending/descending stairs in a population with hemiparesis has been addressed in isolation using several instruments that separately measure items including the total ascent/ descent time ${ }^{3,16}$, cadence $^{7}$, handrail use ${ }^{17-19}$, type of step ${ }^{17-19}$, need for external assistance ${ }^{4,17-22}$, level of difficulty ${ }^{4,23,24}$, and use of an auxiliary device ${ }^{4}$, among others. However, these characteristics have not been jointly evaluated using any instrument. Although there are instruments that evaluate qualitative kinematic gait characteristics ${ }^{25}$ and tests such as the Timed Up and Go (TUG) test ${ }^{26,27}$, no available instrument evaluates the strategies used to ascend/descend stairs. Thus, through the instrument developed in the present study ${ }^{28}$, it was hoped that it would be possible to identify not only descriptive items (such as cadence or need for assistance) and general characteristics (such as the use of an auxiliary device or handrail) but also strategies adopted by individuals with hemiparesis who can ascend/descend stairs with/without external assistance (orthoses and/or help from another person). An activity performance analysis was conducted using video and allowed more consistent input to identify key deficits in stair ascent/descent and guided the best strategies for stroke motor rehabilitation.

The first version of the instrument consisted of 80 items described in three domains: general characteristics, functional performance, and strategies adopted in the ascent and descent of stairs. Each item was developed from an extensive literature search,

\footnotetext{
${ }^{1}$ Programa de Pós-graduação em Ciências do Movimento Humano, Universidade do Estado de Santa Catarina (UDESC), Florianópolis, SC, Brasil ${ }^{2}$ Departamento de Fisioterapia, Universidade Federal de Minas Gerais (UFMG), Belo Horizonte, MG, Brasil

Received: 09/19/2013 Revised: 02/14/2014 Accepted: 02/27/2014
} 
expert opinion and a qualitative kinematic analysis of the ascent/descent of stairs ${ }^{28}$. However, to be eligible for application, all items and the entire instrument were evaluated and validated by a panel of experts ${ }^{29,30}$.

A content validation certifies whether an instrument measures what is intended and verifies whether the items properly reflect the content domain of interest and whether the scale dimensions are consistent with each proposed item and fulfill the specific objectives inde ${ }^{29,31}$. Content validity aspects include the appropriateness, clarity and comprehensiveness of items, which are classified by an evaluation of the instrument items by a group of experts with previous experience or currently recognized competence in the field of study, namely judges or experts ${ }^{29,32-34}$. Despite its great importance, the process of content validation of original instruments is poorly described in the literature, which most often reports on the translation and cross-cultural adaptation of instruments. Therefore, the present study aimed to validate the content of a developed instrument to assess the qualitative kinematic characteristics and strategies adopted in the ascent and descent of stairs by individuals with hemiparesis.

\section{Method}

The stages for the development and validation of an instrument encompass four distinct phases: planning, construction, quantitative analysis, and validation ${ }^{29}$. The instrument planning and construction phases, described by Natalio et al. ${ }^{28}$, consisted of an extensive literature review, expert opinion and qualitative kinematic analysis of stair ascent/descent by individuals with hemiparesis because of stroke. Content validation is described in the present study. This project was approved according to protocol no. 42/2008 of the Human Research Ethics Committee, Universidade do Estado de Santa Catarina (UDESC), Florianópolis, Santa Catarina state, Brazil.

\section{Participants}

According to the protocol described by Polit et al. ${ }^{33}, 8$ Brazilian and Canadian researchers, with proven scientific track records in the field of motor rehabilitation of individuals with hemiparesis and knowledge of the biomechanics of stairs ascent and descent, were invited to participate in the present study. The length of experience of the participants ranged from 8 to 25 years, and among the 7 researchers who agreed to participate, two had Master's degrees and 5 had Doctoral degrees in the area of study. The experts reported having an excellent or good knowledge of hemiparesis, motor rehabilitation and biomechanics of stair ascent and descent. In the first phase of content validation, 7 experts, four Brazilians and three Canadians, responded within a specified period. In the second and third phases, 5 specialists participated: two Brazilians and three Canadians.

\section{Procedures}

Three phases of content validation were performed, in which the initial and modified versions of the instrument were subjected to content validity by a committee of 7 experts with representation and recognition in the area of interest of this study. Thus, a content validation questionnaire was developed in both Portuguese and English, which evaluated the consistency, representativeness, relevance and clarity of each item developed ${ }^{26,27,32-35}$.

\section{Statistical analysis}

The content validity of the developed instrument was statistically analyzed by a Content Validity Index (CVI). To calculate the CVI, each item was ranked on a four-point scale $(1=$ not relevant, $2=$ somewhat relevant, 3 = quite relevant, $4=$ highly relevant). For each item, the CVI was calculated as the number of experts who provided a rank of 3 or 4 , divided by the total number of experts. The Kappa Modified Coefficient was used to determine the degree of relevance agreement of the CVI and was calculated according to Polit et al. ${ }^{33}$.

Seven experts participated in the first phase of content validation, the acceptable CVI value for each item ranged from 1.00 to 0.71 , and the Kappa Modified value from 1.00 to 0.65 . In the second and third phases, the items considered as acceptable were those that had a CVI ranging from 1.00 to 0.80 and a Modified Kappa value ranging from 1.00 to 0.76 because 5 specialists participated in these phases ${ }^{31}$. Because the CVI considered the number of experts consulted for each phase, the difference in the number of experts in the different content validation phases of the present study did not influence the statistical results.

\section{Results}

The first version of the instrument was developed with a total of 80 items divided into three domains: general characteristics (6 items), functional performance (23 items), ascent strategies adopted (25 items) and descent strategies adopted (26 items). The functional performance domain presented 
18 common items for the ascent and descent of stairs, in addition to two items related to the ascent and three items related to the descent of stairs. In the adopted strategies domain, 25 items were identical for ascent and descent; however, the items were evaluated separately at different phases of content validation ${ }^{28}$.

\section{The first phase of content validation}

In the first phase of content validation, the domains were considered satisfactory (CVI between 0.71 and $1.00)^{33}$ for evaluating the ascent and descent of stairs, and the Adopted Strategies Domain, for both ascent and descent, demonstrated that major corrections were necessary.

Most items in the General Characteristics Domain obtained satisfactory scores (Table 1). All items in this domain were maintained in the second version of the instrument, but the first two items that assessed the number of stair steps and use of orthoses, respectively, were transferred to a descriptive domain with no specific score. The items that assessed the confidence level and functional graduation had their wording changed for improved understanding.

Table 2 presents the common scores of the Functional Performance Domain for the ascent and descent of stairs. The initial two items, which assessed the cadence of the ascent and descent of stairs, were transferred to the descriptive domain (no score), and item 9 , which evaluated the lower limb that initiates movement, was moved to the domain that separately evaluated ascent and descent. Items 2 and 8 were maintained without correction, and items 4, 6, 7 and 16 were excluded.

In the Functional Performance Domain, items related to stair ascent, item 1 , which assessed the need for assistance during the ground-stair transition, was excluded, despite having CVI and Kappa values that were near acceptable for characteristics such as relevance and clarity (CVI=0.71 and Kappa $=0.65)$. According to the experts, this item assessed aspects not exclusively related to performance on the stairs, such as the gait on a flat surface. In the identical domain, item 2, which assessed the collision of the foot with the step, did not achieve acceptable scores for the characteristics of consistency $(\mathrm{CVI}=0.57$ and Kappa $=0.56$ ) or clarity $(\mathrm{CVI}=0.28$ and Kappa $=0.26)$ and required modification.

In the Functional Performance Domain, the items related to the descent of stairs, item 1 , which assessed the need for assistance during the threshold-step transition, was excluded because of low CVI and Kappa values for most characteristics analyzed. Item 2, which assessed the need for assistance during the last step-ground transition had its wording changed to better adapt it to the evaluation of stair descent because it had low CVI and Kappa values for consistency and representativeness (CVI $=0.57$ and Kappa $=0.56$ ). Item 3, which evaluated the safety in reaching the lower step with the foot, did not have a satisfactory score for the representativeness characteristic $(\mathrm{CVI}=0.57$ and Kappa $=0.56)$ and had its wording corrected. Furthermore, a change was performed for items 2 and 3 of this domain.

Regarding the domains developed in the first version of the instrument, according to the suggestion of one of the experts, the items of the Functional Performance Domain were included in the General Characteristics Domain. Thus, the second version of the instrument was subdivided into the General Characteristics and Adopted Strategies domains.

The items of the Adopted Strategies Domain for the ascent and descent of stairs were assessed as

Table 1. The first phase of content validation of the General Characteristics Domain.

\begin{tabular}{|c|c|c|c|c|c|c|c|c|c|}
\hline \multirow{3}{*}{ Items } & \multicolumn{9}{|c|}{ General characteristics - common items of stair ascent and descent } \\
\hline & \multicolumn{2}{|c|}{ Consistency } & \multicolumn{2}{|c|}{ Represent.** } & \multicolumn{2}{|c|}{ Relevance } & \multicolumn{2}{|c|}{ Clarity } & \multirow{2}{*}{ Results } \\
\hline & CVI* & Kappa & CVI* & Kappa & IVC* & Kappa & CVI* & Kappa & \\
\hline 1. Number of steps & 0.86 & 0.85 & 0.71 & 0.65 & 0.86 & 0.85 & 1.00 & 1.00 & Domain change \\
\hline 2. Use of orthoses & 0.86 & 0.85 & 0.86 & 0.85 & 1.00 & 1.00 & 1.00 & 1.00 & Domain change \\
\hline 3.1 Level of confidence & 0.71 & 0.65 & 0.86 & 0.85 & 0.86 & 0.85 & 0.43 & 0.41 & Corrected \\
\hline $\begin{array}{l}3.2 \text { Level of confidence } \\
\text { with a handrail }\end{array}$ & 0.71 & 0.65 & 0.86 & 0.85 & 0.86 & 0.85 & 0.71 & 0.65 & Corrected \\
\hline $\begin{array}{l}\text { 3.3 Level of confidence } \\
\text { without a handrail }\end{array}$ & 0.71 & 0.65 & 0.86 & 0.85 & 0.86 & 0.85 & 0.71 & 0.65 & Corrected \\
\hline 4. Functional graduation & 0.57 & 0.56 & 0.71 & 0.65 & 0.86 & 0.85 & 0.86 & 0.85 & Corrected \\
\hline
\end{tabular}

*CVI: Content validity index; **Representativeness/relevance to the field of interest. 
barely relevant by two of the 7 experts. Because this domain was similarly assessed by all experts for both the ascent and descent of stairs, and because it was a long domain, we opted to unite both sections (ascent and descent) with respect to the layout of the instrument.

The items that did not reach acceptable levels in all analyzed characteristics (i.e. consistency, representativeness, relevance and clarity) by CVI and Modified Kappa Coefficient were excluded:

- Trunk: trunk and pelvis rotation in the transition phase $(0.57 \leq \mathrm{CVI} \leq 0.71)$;

- Hip: adduction $(0.43 \leq \mathrm{CVI} \leq 0.57)$;
- Knee:internal rotation $(0.43 \leq \mathrm{CVI} \leq 0.57)$; external rotation $(0.28 \leq \mathrm{CVI} \leq 0.57)$; varus $(\mathrm{CVI}=0.43)$; valgus $(\mathrm{CVI}=0.43)$;

- Joint stability: all items were excluded for both ascent and descent $(\mathrm{CVI}=0.43)$.

Regarding the score of this domain, a need for score standardization for all segments evaluated was observed with only one score description maintained: (0) no deviation or the deviation was small; (1) moderate deviation; and (2) severe deviation, which greatly hindered accomplishing the task.

Table 2. The first phase of the content validation of the functional performance Domain - common items of stair ascent and descent.

\begin{tabular}{|c|c|c|c|c|c|c|c|c|c|}
\hline \multirow{3}{*}{ Items } & \multicolumn{8}{|c|}{ Functional performance - common items of stair ascent and descent } & \multirow{3}{*}{ RESULTS } \\
\hline & \multicolumn{2}{|c|}{ Consistency } & \multicolumn{2}{|c|}{ Represent.** } & \multicolumn{2}{|c|}{ Relevance } & \multicolumn{2}{|c|}{ Clarity } & \\
\hline & CVI* & Kappa & CVI* & Kappa & IVC* & Kappa & CVI* & Kappa & \\
\hline A. Ascent cadence & 0.71 & 0.65 & 0.86 & 0.85 & 0.86 & 0.85 & 0.86 & 0.85 & Domain change \\
\hline B. Descent cadence & 0.71 & 0.65 & 0.86 & 0.85 & 0.86 & 0.85 & 0.86 & 0.85 & Domain change \\
\hline 1. External assistance & 0.86 & 0.85 & 0.86 & 0.85 & 1.00 & 1.00 & 0.86 & 0.85 & VALIDATED \\
\hline 2. Handrail & 0.71 & 0.65 & 0.86 & 0.85 & 0.86 & 0.85 & 0.86 & 0.85 & Corrected \\
\hline $\begin{array}{l}\text { 3. Intensity of handrail } \\
\text { use }\end{array}$ & 0.86 & 0.85 & 0.71 & 0.65 & 0.71 & 0.65 & 0.43 & 0.41 & Corrected \\
\hline $\begin{array}{l}\text { 4. Positioning of the } \\
\text { upper limbs }\end{array}$ & 0.71 & 0.65 & 0.71 & 0.65 & 0.57 & 0.56 & 0.57 & 0.56 & EXCLUDED \\
\hline $\begin{array}{l}\text { 5. Position of the paretic } \\
\text { upper limb }\end{array}$ & 0.86 & 0.85 & 0.57 & 0.56 & 0.57 & 0.56 & 0.57 & 0.56 & Corrected \\
\hline 6. Balance reactions & 0.57 & 0.56 & 0.57 & 0.56 & 0.57 & 0.56 & 0.43 & 0.41 & EXCLUDED \\
\hline $\begin{array}{l}\text { 7. Balance of the upper } \\
\text { limbs }\end{array}$ & 0.71 & 0.65 & 0.57 & 0.56 & 0.57 & 0.56 & 0.43 & 0.41 & EXCLUDED \\
\hline 8. Pace pattern & 1.00 & 1.00 & 1.00 & 1.00 & 1.00 & 1.00 & 1.00 & 1.00 & VALIDATED \\
\hline $\begin{array}{l}\text { 9. Lower limb that } \\
\text { initiates the movement }\end{array}$ & 0.71 & 0.65 & 1.00 & 1.00 & 1.00 & 1.00 & 1.00 & 1.00 & Domain change \\
\hline 10. Supporting time & 0.86 & 0.85 & 1.00 & 1.00 & 0.86 & 0.85 & 0.86 & 0.85 & VALIDATED \\
\hline $\begin{array}{l}\text { 11. Relative speed of } \\
\text { movement }\end{array}$ & 0.57 & 0.56 & 0.71 & 0.65 & 0.86 & 0.85 & 0.86 & 0.85 & Corrected \\
\hline $\begin{array}{l}\text { 12. Activity execution } \\
\text { strategy }\end{array}$ & 0.57 & 0.56 & 0.71 & 0.65 & 0.86 & 0.85 & 0.43 & 0.41 & Corrected \\
\hline $\begin{array}{l}\text { 13. Positioning strategy } \\
\text { of the feet }\end{array}$ & 0.71 & 0.65 & 0.86 & 0.85 & 0.86 & 0.85 & 0.71 & 0.65 & Corrected \\
\hline 14. Foothold on the step & 0.57 & 0.56 & 0.71 & 0.65 & 0.71 & 0.65 & 0.43 & 0.41 & Corrected \\
\hline 15. Initial foot contact & 0.43 & 0.41 & 0.86 & 0.85 & 0.86 & 0.85 & 0.71 & 0.65 & Corrected \\
\hline 16. Plantar support & 0.57 & 0.56 & 0.57 & 0.56 & 0.57 & 0.56 & 0.57 & 0.56 & EXCLUDED \\
\hline
\end{tabular}

*CVI: Content validity index; **Representativeness/relevance to the field of interest. 


\section{Second phase of contents validation}

The second version of the instrument was resubmitted to the expert committee for an evaluation of 39 items. Among these items, only four did not require a content validity assessment because they had acceptable CVI and Kappa values in the first validation phase. Thus, 35 items were reassessed in the second phase of content validation.

Table 3, which describes the second validation phase of items in the General Characteristics Domain, indicates that most items achieved satisfactory CVI and Kappa values, except items 5, 6 and 9 for the relevance characteristic and items 4, 6 and 12 for the clarity characteristic. These items were corrected and subjected to a third phase of content validation.

Table 4 shows the results of the content validity evaluation of the characteristics analyzed for each item in the General Characteristics Domain: items related to the ascent of stairs. Two items had appropriate levels of content validity, and only item 2 , which assessed the collision of the foot and step, was considered to have deficits in clarity/possibility of comprehension (wording), which required correction. Similarly, the items in the General Characteristics Domain, items related to the descent of stairs, reached adequate levels of content validity. Only item 2, which assessed the safety in reaching the lowest step with the foot during stair descent, had low CVI and Kappa values for the relevance characteristics for clinical interpretation, which could be performed based on measurement, and clarity/possibility of lack of comprehension (wording).

In the Adopted Strategies Domain, all items developed for the trunk/pelvis, hip, knee and ankle reached adequate levels of content validity for all four characteristics analyzed with CVI values ranging between 0.80 and 1.00 and a Kappa ranging between 0.76 and 1.00 . The only item with a low score assessed the anteversion/retroversion of the pelvis, as shown in Table 4. This item was thus excluded from the final version of the instrument.

\section{Third phase of content validation}

Altogether, 10 items in the General Characteristics Domain were analyzed in the third phase of content validation: items common to the ascent and descent of stairs and items related to the ascent and to the descent of stairs. Table 5 shows that all items subjected to this phase were validated after the appropriate corrections.

Table 3. The second phase of content validation of the general characteristics domain.

\begin{tabular}{|c|c|c|c|c|c|c|c|c|c|}
\hline \multicolumn{10}{|c|}{ General characteristics - common items of stair ascent and descent } \\
\hline \multirow{2}{*}{ Item } & \multicolumn{2}{|c|}{ Consistency } & \multicolumn{2}{|c|}{ Represent.** } & \multicolumn{2}{|c|}{ Relevance } & \multicolumn{2}{|c|}{ Clarity } & \multirow{2}{*}{ Results } \\
\hline & CVI* & Kappa & CVI* & Kappa & IVC* & Kappa & CVI* & Kappa & \\
\hline 1.1 Level of Confidence & 1.00 & 1.00 & 1.00 & 1.00 & 1.00 & 1.00 & 1.00 & 1.00 & VALIDATED \\
\hline $\begin{array}{l}1.2 \text { Level of Confidence } \\
\text { with a handrail }\end{array}$ & 1.00 & 1.00 & 1.00 & 1.00 & 1.00 & 1.00 & 1.00 & 1.00 & VALIDATED \\
\hline $\begin{array}{l}\text { 1.3 Level of Confidence } \\
\text { without a handrail }\end{array}$ & 1.00 & 1.00 & 1.00 & 1.00 & 1.00 & 1.00 & 1.00 & 1.00 & VALIDATED \\
\hline 2. Functional graduation & 1.00 & 1.00 & 1.00 & 1.00 & 1.00 & 1.00 & 1.00 & 1.00 & VALIDATED \\
\hline 4. Use of a handrail & 0.80 & 0.76 & 0.80 & 0.76 & 0.80 & 0.76 & 0.60 & 0.54 & Corrected \\
\hline $\begin{array}{l}\text { 5. Intensity of use of a } \\
\text { handrail }\end{array}$ & 0.80 & 0.76 & 0.80 & 0.76 & 0.60 & 0.54 & & & Corrected \\
\hline $\begin{array}{l}\text { 6. Position of the paretic } \\
\text { upper limb }\end{array}$ & 0.80 & 0.76 & 0.80 & 0.76 & 0.60 & 0.54 & 0.60 & 0.54 & Corrected \\
\hline $\begin{array}{l}\text { 9. Relative speed of lower } \\
\text { limb movement }\end{array}$ & 1.00 & 1.00 & 0.80 & 0.76 & 0.60 & 0.54 & 0.80 & 0.76 & Corrected \\
\hline 10. Body alignment & 0.80 & 0.76 & 0.80 & 0.76 & 0.80 & 0.76 & 0.80 & 0.76 & Corrected \\
\hline 11. The feet of alignment & 0.80 & 0.76 & 1.00 & 1.00 & 0.80 & 0.76 & 0.80 & 0.76 & Corrected \\
\hline 12. Foothold & 0.80 & 0.76 & 0.80 & 0.76 & 0.80 & 0.76 & 0.60 & 0.54 & Corrected \\
\hline 13. Initial foot contact & 0.80 & 0.76 & 0.80 & 0.76 & 0.80 & 0.76 & 0.80 & 0.76 & Corrected \\
\hline
\end{tabular}

*CVI: Content validity index; **Representativeness/relevance to the field of interest. 


\section{Discussion}

Content validity is related to the robustness of score interpretations of an instrument and indicates the degree to which these scores measure what they claim to measure ${ }^{35,36}$. In the present study, three content validation phases were performed for the final set of items to obtain a consensus among the experts. According to Benson and Clark ${ }^{29}$, when absolute agreement is not reached for an item, the item must be revised until a consensus is reached. However, some items will never reach this standard despite several revisions and should therefore be excluded from the instrument. In this context, the first phase of content validation in the present study enabled a significant reduction in the size of the instrument with the exclusion of 41 items, including 15 that were excluded and 26 that were added to the Adopted Strategies Domain of the ascent and descent of stairs. Among the 15 items that were excluded, 6 belonged to the General Characteristics Domain and 9 belonged to the Adopted Strategies Domain. The items in the General Characteristics Domain that did not reach satisfactory levels of content validity were considered to have no value for the Instrument Content Domain. The 9 items excluded from the Adopted Strategies Domain assessed range of motion and compensations deemed incompatible with the qualitative kinematic analysis. In this first phase, important changes were also performed in the item wordings for better understanding, and therefore, the instrument was subjected to a re-evaluation of its content validity.
The results of the content validation process were determined by the CVI and Modified Kappa Coefficient. According to Polit et al..$^{33}$, the items that presented CVI and Modified Kappa values above 0.70 were considered good and excellent. Thus, considering the final version of the instrument, it was observed that for the 38 items, 6 were validated in the first phase of content validity, 22 in the second phase and ten in the third and final phase. Nevertheless, in the first validation phase, $57.5 \%$ of the items reached acceptable levels (above 0.70 ) of content validity and Modified Kappa Coefficients for the consistency characteristic, $56.2 \%$ for representativeness, $50 \%$ for relevance and $32.5 \%$ for clarity. However, corrections were suggested by experts, thus justifying a re-evaluation. In the second validation phase, $81.6 \%$ of the items reached acceptable levels (above 0.70) for the characteristics of consistency and representativeness, $65.8 \%$ for relevance and $71 \%$ for clarity. The final 10 items subjected to the third evaluation reached acceptable levels and were considered validated in the aspects evaluated.

The final version of the clinical assessment instrument of the ascent and descent of stairs for individuals with hemiparesis had 38 items divided into 8 descriptive items: 16 items in the General Characteristics Domain for the ascent and descent of stairs and 14 items in the Adopted Strategies Domain for the ascent and descent of stairs (Appendix 1). Each item was assessed by an ordinal, categorical scale ranging from zero to two points that corresponded to the best and worst performance, respectively. The total score of the instrument was calculated separately for the ascent ( $0-70$ points) and descent ( $0-74$ points)

Table 4. The second phase of content validation of the independent items of the stair ascent and descent.

\begin{tabular}{|c|c|c|c|c|c|c|c|c|c|}
\hline \multicolumn{10}{|c|}{ General characteristics - items referring to stair ascent } \\
\hline \multirow{2}{*}{ Items } & \multicolumn{2}{|c|}{ Consistency } & \multicolumn{2}{|c|}{ Represent.** } & \multicolumn{2}{|c|}{ Relevance } & \multicolumn{2}{|c|}{ Clarity } & \multirow{2}{*}{ Results } \\
\hline & CVI* & Kappa & CVI* & Kappa & IVC* & Kappa & CVI* & Kappa & \\
\hline $\begin{array}{l}\text { 1. Lower limb that } \\
\text { initiates stair ascent }\end{array}$ & 1.00 & 1.00 & 1.00 & 1.00 & 0.80 & 0.76 & 1.00 & 1.00 & VALIDATED \\
\hline $\begin{array}{l}\text { 2. Collision of the foot } \\
\text { with the step }\end{array}$ & 0.80 & 0.76 & 1.00 & 1.00 & 1.00 & 1.00 & 0.60 & 0.54 & Corrected \\
\hline \multicolumn{10}{|c|}{ General characteristics - items referring to stair descent } \\
\hline $\begin{array}{l}\text { 1. Lower limb that } \\
\text { initiates stair descent }\end{array}$ & 1.00 & 1.00 & 1.00 & 1.00 & 0.80 & 0.76 & 1.00 & 1.00 & VALIDATED \\
\hline $\begin{array}{l}\text { 2. Safety during stair } \\
\text { descent }\end{array}$ & 0.80 & 0.76 & 0.80 & 0.76 & 0.60 & 0.54 & 0.60 & 0.54 & Corrected \\
\hline 3. Need for aids & 0.80 & 0.76 & 1.00 & 1.00 & 0.80 & 0.76 & 0.80 & 0.76 & Corrected \\
\hline
\end{tabular}

*CVI: Content validity index; **Representativeness/relevance to the field of interest. 
Table 5. The third phase of content validation of the general characteristics domain.

\begin{tabular}{|c|c|c|c|c|c|c|c|c|c|}
\hline \multirow{3}{*}{ Items } & \multicolumn{9}{|c|}{ General characteristics - common items of stair ascent and descent } \\
\hline & \multicolumn{2}{|c|}{ Consistency } & \multicolumn{2}{|c|}{ Represent.** } & \multicolumn{2}{|c|}{ Relevance } & \multicolumn{2}{|c|}{ Clarity } & \multirow{2}{*}{ Results } \\
\hline & CVI* & Kappa & CVI* & Kappa & IVC* & Kappa & CVI* & Kappa & \\
\hline $\begin{array}{l}\text { - Use of a handrail and } \\
\text { upper limbs }\end{array}$ & 1.00 & 1.00 & 1.00 & 1.00 & 1.00 & 1.00 & 0.80 & 0.76 & VALIDATED \\
\hline $\begin{array}{l}\text { - Time of use of a } \\
\text { handrail }\end{array}$ & 1.00 & 1.00 & 1.00 & 1.00 & 1.00 & 1.00 & 1.00 & 1.00 & VALIDATED \\
\hline $\begin{array}{l}\text { - Position of the upper } \\
\text { limbs }\end{array}$ & 0.80 & 0.76 & 0.80 & 0.76 & 0.80 & 0.76 & 0.80 & 0.76 & VALIDATED \\
\hline $\begin{array}{l}\text { - Symmetry of the lower } \\
\text { limb support time }\end{array}$ & 0.80 & 0.76 & 0.80 & 0.76 & 1.00 & 1.00 & 0.80 & 0.76 & VALIDATED \\
\hline - Body alignment & 0.80 & 0.76 & 1.00 & 1.00 & 1.00 & 1.00 & 0.80 & 0.76 & VALIDATED \\
\hline $\begin{array}{l}\text { - Feet alignment on the } \\
\text { step }\end{array}$ & 1.00 & 1.00 & 1.00 & 1.00 & 1.00 & 1.00 & 1.00 & 1.00 & VALIDATED \\
\hline - Foothold on the step & 1.00 & 1.00 & 1.00 & 1.00 & 1.00 & 1.00 & 0.80 & 0.76 & VALIDATED \\
\hline
\end{tabular}

General characteristics - items referring to stair ascent

\begin{tabular}{llllllllll}
$\begin{array}{l}\text { - Collision of the foot } \\
\text { during stair ascent }\end{array}$ & 1.00 & 1.00 & 1.00 & 1.00 & 1.00 & 1.00 & 1.00 & 1.00 & VALIDATED \\
\hline
\end{tabular}

General characteristics - items referring to stair descent

- Difficulty in reaching

$\begin{array}{llllllllll}\begin{array}{l}\text { the lower step during } \\ \text { stair descent }\end{array} & 1.00 & 1.00 & 1.00 & 1.00 & 1.00 & 1.00 & 1.00 & 1.00 & \text { VALIDATED } \\ \text { - Need for aids } & 1.00 & 1.00 & 1.00 & 1.00 & 1.00 & 1.00 & 1.00 & 1.00 & \text { VALIDATED }\end{array}$

*CVI: Content validity index; **Representativeness/relevance to the field of interest.

of stairs. Because of the long instrument format, the major items of each domain are shown in Appendix 1, and the full instrument may be obtained by contacting the authors.

The 38 items that constituted the final version of the instrument presented adequate content validity for assessing the qualitative kinematic characteristics and strategies adopted in the ascent and descent of stairs for individuals with hemiparesis. However, further analytical studies of other psychometric properties, such as inter- and intra-examiner reliability, internal consistency and criterion and construct validity are necessary and will be performed in the future.

\section{References}

1. Verghese J, Wang C, Xue X, Holtzer R. Self-Reported Difficulty in Climbing Up or Down Stairs in Nondisabled Elderly. Arch Phys Med Rehabil. 2008;89:100-4. PMid:18164338 PMCid:PMC2671033. http://dx.doi. org/10.1016/j.apmr.2007.08.129

2. Amaral-Natalio M, Nunes GS, Herber V, Michaelsen SM. Relação entre cadência da subida e descida de escada, recuperação motora e equilíbrio em indivíduos com hemiparesia. Acta Fisiátr. 2011;18(3):146-50.

3. Flansbjer U-B, Holmback AM, Downham D, Patten C, Lexell J. Reliability of gait performance tests in men and women with hemiparesis after stroke. J Rehabil Med. 2005;37:75-82. PMid:15788341. http://dx.doi. org/10.1080/16501970410017215

4. Roorda LD, Roebroeck ME, Van Tilburg T, Lankhorst GJ, Bouter LM. Measuring Mobility Study Group. Measuring activity limitations in climbing stairs: development of a hierarchical scale for patients with lower-extremity disorders living at home. Arch Phys Med Rehabil. 2004;85:967-71. PMid:15179652. http://dx.doi. org/10.1016/j.apmr.2003.11.018

5. Teixeira-Salmela LF, Silva PC, Lima RCM, Augusto ACC, Souza AC, Goulart F. Musculação e condicionamento aeróbio na performance funcional de hemiplégicos crônicos. Acta Fisiatr. 2003;10(2):54-60.

6. Teixeira-Salmela LF, Olney SJ, Nadeau S, Brouwer B. Muscle strengthening and physical conditioning to reduce impairment and disability in chronic stroke survivors. Arch Phys Med Rehabil. 1999;80:1211-8. http://dx.doi. org/10.1016/S0003-9993(99)90018-7

7. Olney S, Elkin N, Lowe P. An ambulation profile for clinical gait evaluation. Physiother Can. 1979;31:85-90. 
8. Carod-Artal FJ, Gonzalez-Gutierrez JL, Herrero JAE, Horan T, Seijas EV. Functional recovery and instrumental activities of daily living: follow-up 1-year after treatment in a stroke unit. Brain Injury. 2002;16(3):207-16. PMid:11874614. http://dx.doi.org/10.1080/02699050110103337

9. Riberto M, Miyazaki MH, Jucá SSH, Lourenço C, Battistella LR. Independência funcional em pessoas com lesões encefálicas adquiridas sob reabilitação ambulatorial. Acta Fisiatr. 2007;14(2):87-94.

10. Alzahrani MA, Dean CM, Ada L. Ability to negotiate stairs predicts free-living physical activity in communitydwelling people with stroke: an observational study. Aust J Physiother. 2009;55(4):277-81. http://dx.doi.org/10.1016/ S0004-9514(09)70008-X

11. Monteiro RBC, Laurentino GEC, Melo PG, Cabral D, Corrêa JCF, Teixeira-Salmela LF. Medo de cair e sua relação com a medida da independência funcional e a qualidade de vida em indivíduos após Acidente Vascular Encefálico. Cienc Saúde Coletiva. 2013;18(7):2017-27. http://dx.doi.org/10.1590/S1413-81232013000700017

12. Doyle PJ. Measuring health outcomes in stroke survivors. Arch Phys Med Rehabil. 2002;83(12):539-43.

13. Nadeau S, Gravel D, Arsenault AB, Bourbonnais D. Plantarflexor weakness as a limiting factor of gait speed in stroke subjects and the compensating role of hip flexors. Clin Biomech. 1999;14:125-35. http://dx.doi.org/10.1016/ S0268-0033(98)00062-X

14. Bujanda E, Nadeau S, Bourbonnais D, Dickstein R. Associations between lower limb impairments, locomotor capacities and kinematic variables in the frontal plane during walking in adults with chronic stroke. J Rehabil Med. 2003;35:259-64. PMid:14664315. http://dx.doi. org/10.1080/16501970310012428

15. Chen G, Patten C, Kothari DH, Zajac FE. Gait differences between individuals with post-stroke hemiparesis and non-disabled controls at matched speeds. Gait Posture. 2005;22:51-6. PMid:15996592. http://dx.doi. org/10.1016/j.gaitpost.2004.06.009

16. Conte ANF, Ferrari PP, Carvalho TB, Relvas PCA, Neves RCM, Rosa SF. Reliability, comprehension and acceptability of the Portuguese version of the Motor Assessment Scale in stroke patients. Rev Bras Fisioter. 2009;13(5):405-11. http://dx.doi.org/10.1590/ S1413-35552009005000056

17. Bohannon RW, Walsh S. Association of paretic lower extremity muscle strength and standing balance with stair-climbing ability in patients with stroke. J Stroke Cerebrovas Dis. 1991;1(3):129-33. http://dx.doi. org/10.1016/S1052-3057(10)80004-7

18. Lin JH, Hsu MJ, Hsu HW, Wu HC, Hsieh CL. Psychometric Comparisons of 3 Functional Ambulation Measures for Patients With Stroke. Stroke. 2010;41:202125. PMid:20671244. http://dx.doi.org/10.1161/ STROKEAHA.110.589739

19. De Castro SM, Perracini MR, Ganança FF. Versão brasileira do Dynamic Gait Índex. Rev Bras
Otorrinolaringol. 2006;72(6):817-25. http://dx.doi. org/10.1590/S0034-72992006000600014

20. Mahoney FI, Barthel D. Functional evaluation: the Barthel Index. Maryland St Med J. 1965;14:56-61.

21. Riberto M, Miyazaki MH, Juçá SSH, Sakamoto H, Pinto PPN, Battistella LP. Validação da versão brasileira da medida de independência funcional. Acta Fisiatr. 2004;11(2):72-6.

22. Collen FM, Wade DT, Robb GF, Bradshan CM. The Rivermead Mobility Index: a further development. Riverm Motor Asses Inter Durabil Stud. 1991;13:50-4.

23. Williams LS, Weinberger M, Harris LE, Clark DO, Biller J. Development of a stroke-specific quality of life scale. Stroke. 1999;30(7):1362-9. PMid:10390308. http://dx.doi. org/10.1161/01.STR.30.7.1362

24. Lima RCM, Teixeira-Salmela LF, Magalhaes LC, GomesNeto M. Psychometric properties of the Brazilian version of the Stroke Specifi c Quality of Life Scale: application of the Rasch model. Rev Bras Fisioter. 2008;12(2):149-56.

25. Lord SE, Halligan PW, Wade DT. Visual gait analysis: the development of a clinical assessment and scale. Clin. Rehabil. 1998;12:107-19. http://dx.doi. org/10.1191/026921598666182531

26. Faria CDCM, Teixeira-Salmela LF, Nadeau S. Development and validation of an innovative tool for the assessment of the biomechanical strategies: The TUG-ABS for individuals with stroke. J Rehabil Med. 2013;45(3):232-40. PMid:23389698. http://dx.doi. org/10.2340/16501977-1107

27. Faria CDCM, Teixeira-Salmela LF, Nadeau S. Clinical testing of an innovative tool for the assessment of biomechanical strategies: The Timed a Up and Go Assessment of Biomechanical Strategies (TUG-ABS) for individuals with stroke. J Rehabil Med. 2013;45:241-7. PMid:23462895. http://dx.doi. org/10.2340/16501977-1106

28. Natalio MA, Michaelsen SM, Nunes GS, Virtuoso JF, Faria CDCM, Teixeira-Salmela LF. Etapas de desenvolvimento de um instrumento de avaliação clínica da subida e descida de escada em indivíduos com hemiparesia. Ter Man. 2011;9(44):334-42.

29. Benson J, Clark F. A guide for instrument development and validation. Am J Occup Ther. 1982;36(12):789-800. http://dx.doi.org/10.5014/ajot.36.12.789

30. Berk RA. Importance of expert judgement in contentrelated validity evidence. West J Nurs Res. 1990;2(5):65971. http://dx.doi.org/10.1177/019394599001200507

31. Davis AE. Instrument development: Getting Started. J Neurosc Nurs. 1996;28(3):204-7. http://dx.doi. org/10.1097/01376517-199606000-00009

32. Polit DF, Beck CT. The content validity index:are you sure you know what's being reported? critique and recommendations. Res Nurs Health. 2006;29:489-97. PMid:16977646. http://dx.doi.org/10.1002/nur.20147

33. Polit DF, Beck CT, Owen ST. Focus on research methods is the cvi an acceptable indicator of content 
validity? Appraisal and recommendations. Res Nurs Health. 2007;30:459-67. PMid:17654487. http://dx.doi. org/10.1002/nur.20199

34. Gadotti IC, Vieira ER, Magee DJ. Importância e esclarecimento das propriedades de medida em reabilitação. Rev Bras Fisioter. 2006;10(2):137-46. http:// dx.doi.org/10.1590/S1413-35552006000200002

35. Grant JS, Davis LL. Selection and use of content experts for instrument development. Res Nurs Health. 1997;20:26974. http://dx.doi.org/10.1002/(SICI)1098240X(199706)20:3<269::AID-NUR9>3.0.CO;2-G

36. Wynd CA, Schmidt B, Schaefer MA. Two quantitative approaches for estimating content validity. Western
J Nurs Res. 2003;25(5):508-18. http://dx.doi. org/10.1177/0193945903252998

\section{Correspondence}

\section{Mavie Amaral Natalio}

Universidade do Estado de Santa Catarina (UDESC)

Laboratório de Controle Motor (LADECOM)

Rua Pascoal Simone, 358, Coqueiros

CEP 88080-350, Florianópolis, SC, Brasil

e-mail:mavie_fisio@yahoo.com.br 
Appendix 1. The clinical assessment instrument of stair ascent and descent in individuals with hemiparesis - major items.

\section{DESCRIPTIVE ITEMS (which will not be scored)}

Number of steps: ( ) 4 ( ) 5 ( ) 6

Ascent cadence: steps/minute Descent cadence: steps/minute

Use of orthoses: ( ) Without orthoses ( ) With orthoses Type of orthoses:

Functional graduation (this item should be completed after the conclusion of the analysis of ascending and descending the stairs)

(0) The task is completed without difficulty or with mild difficulty

(1) The task or certain steps are performed with significant difficulty or might require assistance by the examiner up to $25 \%$ of the task

(2) The task is completed with the assistance of the examiner in $50 \%$ or more of the task

I - GENERAL CHARACTERISTICS DOMAIN (scored)

\section{COMMON ITEMS OF STAIR ASCENT AND DESCENT}

Ascent Descent

1 - Need for external assistance (assistive devices or personal assistance)

(0) No need for external help

(1) Need for gait devices

012012

(2) Need for personal assistance

2 - Use of a handrail and the upper limbs

(0) Does not use the handrail

(1) Uses only one hand on the handrail for support

(2) Uses both hand on the handrail for support

\section{ITEMS REFERRING TO STAIR ASCENT}

12 - Lower limb that initiates the movement

(0) Paretic lower limb

(1) Mixed (alternates between paretic and non-paretic limbs)

(2) Non-paretic lower limb

13 - Collision of the foot with the step during stair ascent

(0) Reaches the upper step without bumping the foot

(1) Collision of the foot with the upper step is observed BUT without loss of balance

(2) Collision of the foot with the upper step is observed AND with imbalance

\section{ITEMS REFERRING TO THE STAIR DESCENT}

14 - Lower limb that initiates the movement

(0) Non-paretic lower limb

(1) Mixed (alternates between paretic and non-paretic limbs)

(2) Paretic lower limb

15 - Difficulty in reaching the lower step during stair descent

(0) Reaches the lower step without or with mild difficulty

(1) Reaches the lower step with moderate difficulty with minimal interference in performing the activity

(2) Reaches the lower step with severe difficulty, seriously interfering in performing the activity

\section{II - ADOPTED STRATEGIES DOMAIN (scored)}

For these segments, use the following scores:

(0) None or mild deviations

(1) Moderate deviations

(2) Severe deviations and considerably difficulty performing the task

\begin{tabular}{|c|c|c|c|c|}
\hline \multirow{2}{*}{ Strategy } & \multicolumn{2}{|c|}{ ASCENT } & \multicolumn{2}{|c|}{ DESCENT } \\
\hline & Swing Phase & Stance Phase & Swing Phase & Stance Phase \\
\hline \multirow{2}{*}{$\begin{array}{l}\text { 1. Trunk flexion/ } \\
\text { extension }\end{array}$} & (-) $21012(+)$ & (-) $21012(+)$ & (-) $21012(+)$ & (-) $21012(+)$ \\
\hline & Flexion Extension & Flexion Extension & Flexion Extension & Flexion Extension \\
\hline \multirow{2}{*}{$\begin{array}{l}\text { 2. Lateral trunk } \\
\text { inclination }\end{array}$} & (-) $21012(+)$ & (-) $21012(+)$ & (-) $21012(+)$ & (-) $21012(+)$ \\
\hline & Right & Right & Right & Right \\
\hline
\end{tabular}


Appendix 1. Continued...

II - ADOPTED STRATEGIES DOMAIN (scored)

\begin{tabular}{|c|c|c|c|c|c|c|c|c|}
\hline \multirow{2}{*}{$\begin{array}{l}\text { 3. Lateral pelvic } \\
\text { inclination }\end{array}$} & \multicolumn{2}{|c|}{ (-) $21012(+)$} & \multicolumn{2}{|c|}{ (-) $21012(+)$} & \multicolumn{2}{|c|}{ (-) $21012(+)$} & \multicolumn{2}{|c|}{ (-) $21012(+)$} \\
\hline & $\overleftarrow{\text { Right }}$ & $\overrightarrow{\text { Left }}$ & $\overleftarrow{\text { Right }}$ & $\overrightarrow{\text { Left }}$ & $\overleftarrow{\text { Right }}$ & $\overrightarrow{\text { Left }}$ & Right & $\overrightarrow{\text { Lef }}$ \\
\hline \multirow{2}{*}{$\begin{array}{l}\text { 4. Trunk and pelvis } \\
\text { rotation }\end{array}$} & \multicolumn{2}{|c|}{ (-) $21012(+)$} & \multicolumn{2}{|c|}{ (-) $21012(+)$} & \multicolumn{2}{|c|}{ (-) $21012(+)$} & \multicolumn{2}{|c|}{ (-) $21012(+)$} \\
\hline & Right & Left & Right & Left & Right & Left & Right & Lef \\
\hline
\end{tabular}

The following strategies assess the PARETIC LOWER LIMB

5. Flexion Hip

(-) $21012(+)$

Reduction Excess

6. Abduction Hip

(-) $21012(+)$

Reduction Excess

7. Internal Rotation

Hip

$\stackrel{012(+)}{-\underset{\text { Excess }}{\longrightarrow}}$

(-) $21012(+)$

Reduction Excess

(-) $21012(+)$

$\overleftrightarrow{\text { Reduction Excess }}$

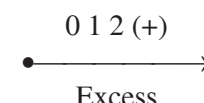

$012(+)$

Excess 